\title{
Establishment of a stable steroidogenic porcine granulosa cell line
}

\author{
P Jorge Chedrese, Marie R Rodway, Cynthia L Swan and Carolina Gillio-Meina.
}

Reproductive Biology Research Unit, Department of Obstetrics and Gynecology, University of Saskatchewan, Saskatoon SK S7N OW8 CANADA.

(Requests for reprints should be addressed to $\mathrm{P} J$ Chedrese)

\begin{abstract}
We report the establishment and preliminary characterization of a stable steroidogenic granulosa cell line, JC-410. This cell line was obtained by spontaneous immortalization of a primary culture of porcine granulosa cells. Cultured JC-410 cells produced less progesterone than granulosa cells in primary culture. Progesterone synthesis by JC-410 cells was approximately $10 \%$ and $1 \%$ of the amount produced by granulosa cells from small and medium sized follicles, respectively. Although $\mathrm{FSH}$ and $\mathrm{LH}$ did not change progesterone levels in cultured JC-410 cells, forskolin and cholera toxin induced a 2.6- and 2.75-fold increase, respectively, versus control. The JC-410 cells responded to $0.1,1$ and $5 \mathrm{mM}$ cAMP with an increase in progesterone synthesis of 2.5-, 28- and 49-fold versus control, respectively,
\end{abstract}

\section{INTRODUCTION}

The introduction of cell biology methods into endocrine research initiated the study of ovarian granulosa cells in vitro (Channing \& Ledwitz-Rigby 1975, Veldhuis et al. 1980). These studies are commonly conducted in primary cultures, using a uniform population of freshly isolated granulosa cells, often obtained from pre-antral follicles of hypophysectomized, estrogen treated immature rats (Hsueh et al. 1984). Studies are also conducted with primary cultures of granulosa cells from porcine or bovine ovaries collected at the slaughterhouse. Hormonal responsiveness depends on the endocrine status at the time of slaughter and on the stage of maturation of the follicle (Farkash et al. 1986, Zlotkin et al. 1986). Therefore, cultures generated under these conditions are generally heterogeneous, and consequently, the results are highly variable (Lowsky \& Farookhi 1989). Nevertheless, scientists using these models have elucidated key mechanisms by which hormones control granulosa cell differentiation and steroidogenesis (Hsueh et al. 1984, Patton \& Collins 1992, Urban \& Veldhuis 1992, Richards 1994).

In recent years, several laboratories have attempted to circumvent these limitations by establishing stable granulosa cell lines. The original description of a stable granulosa cell line was reported by Zeleznik et al. (1979). Since then, a variety of strategies have been used to immortalize granulosa cells. These include transformation with oncogenes or oncovirus and spontaneous immortalization of primary cultures (reviewed Amsterdam and Selvaraj 1997). Transformation with the E6 and E7 open reading frames of the after a $24 \mathrm{~h}$ incubation. No detectable levels of estradiol-17 $\beta$ were found in JC-410 cells after $48 \mathrm{~h}$ in culture. However, addition of $0.01,0.1$ and $1 \mu \mathrm{M}$ androstenedione elevated the levels of estradiol- $17 \beta$ to $0.028,0.3$ and $1.21 \mathrm{pg} / \mu \mathrm{g}$ protein, respectively. The level of expression of $3 \beta-\mathrm{HSD}$, aromatase and P450scc genes in JC-410 cells is of similar magnitude to the level of expression in granulosa cells in primary culture. The JC- 410 cells have been maintained in culture for more than one year during which their population doubled over 100 times. We conclude that JC-410 is a stable cell line that lost responsiveness to the gonadotropins during the process of immortalization, but retained its steroid biosynthetic capability and the expression of key steroidogenic genes. These characteristics may reflect features of cells arrested in an early stage of granulosa cell differentiation.

human papillomavirus has been used to immortalize human ovarian granulosa cells (Rainey et al. 1994). Transformation with the simian virus 40 (SV40) large $\mathrm{T}$ antigen gene has produced immortalized rat granulosa cells with variable steroidogenic capabilities (Amsterdam et al. 1988, Fitz et al. 1989, Leighton et al. 1993). Co-transformation with the SV40 large $\mathrm{T}$ antigen gene and a ras-oncogene was required to produce highly steroidogenic stable rat granulosa cells (Suh \& Amsterdam 1990). In the present report we describe the establishment, and partial characterization, of a stable cell line obtained by spontaneous immortalization of a primary culture of porcine granulosa cells. During the process of immortalization, these cells have retained several features of normal granulosa cells, including steroid biosynthesis and expression of key steroidogenic genes.

\section{MATERIALS AND METHODS}

\section{Reagents}

Media 199, penicillin, trypsin, streptomycin, amphotericin B (Fungizone ${ }^{\circledR}$ ), new born calf serum (CS), trypan blue stain, and restriction enzymes were purchased from Gibco, Burlington, Ontario. Iodinated progesterone, estradiol-17 $\beta$ and nylon membranes were purchased from Amersham, Arlington Heights, IL, USA. The Bio-Rad DC Protein Assay kit was purchased from Bio-Rad Laboratories, Hercules, CA. Cholera toxin, forskolin, 8-bromoadenosine $3^{\prime}: 5^{\prime}$-cyclic monophosphate (cAMP), androstenedione, progesterone, estradiol-17 $\beta$ and general chemicals for radioimmunoassay, RNA preparation and Northern blotting were purchased from 
Sigma, St. Louis, MO. Ovine FSH and LH were obtained from the National Hormone and Pituitary Program, USDA, Rockville, MD.

\section{Granulosa Cell Cultures and Immortalization}

Granulosa cells were obtained from ovaries of prepubertal gilts collected at the local slaughterhouse. Cultures were established as previously described (Chedrese et al. 1988). Briefly, cells were aspirated with a fine needle from medium-sized (4-6 mm) non-atretic follicles within 1 to $1.5 \mathrm{~h}$ of ovary collection. Follicles were determined to be non-atretic if they were uniformly translucent and vascularized. After collection, granulosa cells were washed three times in media 199 containing $100 \mathrm{IU} / \mathrm{ml}$ penicillin, $100 \mu \mathrm{g} / \mathrm{ml}$ streptomycin, $1 \mu \mathrm{g} / \mathrm{ml}$ Fungizone ${ }^{\circledR}$ (M199) and recovered by centrifugation $(10 \mathrm{~m}$ at $200 \mathrm{x} \mathrm{g})$. Cell viability was determined by trypan blue exclusion. Cells were seeded into $100 \mathrm{~mm}$ diameter plastic cell culture plates (Falcon, Lincoln Park, NJ) at a concentration of $5 \times 10^{6}$ viable cells per $10 \mathrm{ml}$ of culture media. The culture medium was M199 containing $5 \mu \mathrm{g} / \mathrm{ml}$ insulin, $5 \mu \mathrm{g} / \mathrm{ml}$ transferrin, $6.7 \mu \mathrm{g} / \mathrm{ml}$ sodium selenite and $5 \% \mathrm{CS}$. A total of nine identical plates were maintained in a $\mathrm{CO}_{2}$ incubator (Forma Scientific Inc. Marietta, Ohio) at $37^{\circ} \mathrm{C}$ in a water saturated atmosphere of $95 \%$ air and $5 \% \mathrm{CO}_{2}$. When confluent, the cells were passaged with $0.06 \%$ trypsin $/ 0.01 \%$ EDTA (trypsin/EDTA). Cells were maintained in long term culture conditions according to the procedure described by Bernath et al. (1990). Following the initial passage, culture medium was changed weekly. One month after the first passage very few colonies remained alive. During the second month in culture, the remaining live cells were passed, pooled from each group and cultured at a concentration of $5 \times 10^{6}$ viable cells/well in three $25 \mathrm{~mm}$ wells of a plastic cell culture plate. After five months in culture, growth was stagnant but cells remained alive. At the end of the seventh month, several colonies arose. These colonies continued to grow and after three more weeks they were passed into culture plates. During the eighth month, cells started to grow sufficiently to allow collection for screening and frozen storage. Those colonies were screened for progesterone production in 24 well culture plates. Once $70-$ $80 \%$ confluency was attained, culture medium was replaced with fresh serum-free medium with or without cAMP. At the end of incubation, medium was collected for a progesterone assay. A progesterone producing colony was identified, that we named JC-410 cells. These cells also responded to cAMP with an increase in progesterone synthesis.

Primary cultures for comparison studies were established as described for immortalization of granulosa cells. Cells from small (1-3 mm diameter) and medium size follicles were plated in 24 well plastic plates in medium containing $10 \% \mathrm{CS}$ and subsequently cultured in serum-free media. Once $70-80 \%$ confluency was attained, culture medium was replaced with fresh serum-free media containing the treatments. After incubation, media was collected for progesterone assays and cells were collected for counting.

\section{Determination of Progesterone, Estradiol-173, and Cellular Protein Content}

Progesterone content was determined by radioimmunoassay (RIA) in $100 \mu$ l of un-extracted culture medium, as previously described (Chedrese et al., 1988). Progesterone synthesis by primary culture of granulosa cells was similarly assayed. Stable granulosa cells were also tested for estradiol-17 $\beta$ production in the presence or absence of androstenedione. Estradiol-17 $\beta$ was assayed by RIA in $250 \mu$ l of un-extracted culture medium, as previously described ( $\mathrm{Xu}$ et al., 1997). Cells were collected with trypsin/EDTA and counted in a hemocytometer. Cells were washed twice with phosphatebuffer salt solution and solubilized by incubation with a $1 \%$ sodium dodecyl sulphate solution, then cellular protein content was determined with the Bio-Rad DC Protein Assay Kit.

\section{Determination of Population Doubling Time}

Cells were plated in $25 \mathrm{~mm}$ plates, trypsinized and counted every $24 \mathrm{~h}$. Number of generations was determined using the formula $N=N_{\mathrm{o}} \cdot 2^{x}$. Where $N$ is the final cell number, $N_{\mathrm{o}}$ the initial cell number, and $x$ the number of generations of exponential growth (Butler 1991). Population doubling time is equal to the total time elapsed divided by the number of generations.

\section{Northern Blot Analyses}

RNA was isolated by acid phenol/chloroform extraction according to methods described by Chomczynski and Sacchi (1987). Samples of total RNA were denatured, sizefractionated by electrophoresis on a $1 \%$ agarose-formaldehyde gel and transferred onto a nylon membrane (Hybond-N) by diffusion blotting. RNA was crosslinked to the membrane using a UV Stratalinker 1800 (Stratagene, La Jolla, CA). cDNAs for human type II $3 \beta$-hydroxy-5-ene steroid dehydrogenase (3$\beta$-HSD) (Luu The et al., 1989), bovine cytochrome P450-aromatase (aromatase) (Hinshelwood et al., 1993), porcine cytochrome P450- cholesterol side chain cleavage (P450scc) (Mulheron et al., 1989) and mouse glyceraldehyde-3-phosphate dehydrogenase (GAPDH) (Tso et al., 1985) were used as probes. cDNAs were labeled by random primer synthesis (Fainberg and Vogelstein, 1983) with $\left[\alpha^{32} \mathrm{P}\right]$ dCTP ( $>3000 \mathrm{Ci} / \mathrm{mmol}$; New England Nuclear, Boston, MA) to a specific activity of $1.5-3.0 \times 10^{9} \mathrm{dpm} / \mathrm{mg}$ DNA. Membranes were hybridized and washed as was previously described (Chedrese et al., 1990). X-ray films were exposed to the hybridized blotted membranes for $16 \mathrm{~h}$. 
Table 1 Comparative effect of protein kinase-A activators on progesterone systhesis by cultured JC-410 cells and primary culture of granulosa cells from small and medium size follicles.

\begin{tabular}{llll}
\hline & JC-410 Cells & $\begin{array}{l}\text { Small Size Follicles } \\
\text { Granulosa Cells }\end{array}$ & $\begin{array}{l}\text { Medium Size Follicles } \\
\text { Granulosa Cells }\end{array}$ \\
\cline { 2 - 4 } Control & $3.72(0.35)$ & $41.6(3.5)$ & $467(38)$ \\
Forskolin & $9.63(0.5)^{*}$ & $107.5(9.3)^{*}$ & $1392(126)^{\star}$ \\
Cholera Toxin & $10.24(1.0)^{*}$ & $74.15(6.5)^{*}$ & $900(85)^{*}$ \\
FSH & $5.12(0.6)$ & $119.7(12)^{*}$ & $1126(145)^{*}$ \\
LH & $5.1(0.9)$ & $35.7(3.2)$ & $900(87)^{*}$ \\
\hline
\end{tabular}

Cells were cultured for $24 \mathrm{~h}$ in the presence or absence of $10 \mu \mathrm{M}$ forskolin, $10 \mathrm{ng} / \mathrm{ml}$ cholera toxin, $100 \mathrm{ng} / \mathrm{ml} \mathrm{FSH}$ or LH. Progesterone levels are expressed as $\mathrm{pg} / 10^{3}$ cells. Data represent the mean of three replicates \pm SEM. Stars indicates significant differences from each control group.

\section{Statistical analysis}

Data obtained were subjected to analysis of variance. When a significant $F$ value was present, Fisher's Least Significant Difference test was used for individual comparison of means (Steel \& Torrie 1980). Significant differences were established as $\mathrm{p}<0.05$.

\section{RESULTS}

The effects of forskolin, cholera toxin, FSH and LH on progesterone synthesis in JC-410 cells and primary culture of porcine granulosa cells from small and medium size follicles are shown in Table 1. Cultured JC-410 cells produced less progesterone than granulosa cells in primary culture. Progesterone synthesis by $\mathrm{JC}-410$ cells was approximately $10 \%$ and $1 \%$ of the amount produced by granulosa cells from small and medium sized follicles, respectively. FSH and LH did not change progesterone levels in cultured JC-410 cells, but forskolin and cholera toxin induced a 2.6- and 2.75-fold increase, respectively, versus control. In primary cultures of granulosa cells from small size follicles, forskolin, cholera toxin and FSH induced 2.6-, 2.9-, and 2.9-fold increase in progesterone synthesis, respectively, versus control. In these cultures there was no change in progesterone synthesis in response to LH. In primary culture of granulosa cells from medium size follicles, forskolin, cholera toxin, FSH and $\mathrm{LH}$ induced 3.0-, 1.9-, 2.4- and 1.9-fold increase in progesterone synthesis, respectively, versus control.

The effect of cAMP on progesterone synthesis by JC-410 is shown in Fig. 1. cAMP at 0.1, 1 and $5 \mathrm{mM}$ induced 2.5-, 28.0 and 49.0-fold increase in progesterone synthesis, respectively, versus control, after $48 \mathrm{~h}$ in culture.

The effect of the addition of androstenedione, as a substrate for estradiol-17 $\beta$ synthesis by JC-410 cells is shown in Fig. 2 . No detectable levels of estradiol-17- $\beta$ were found in JC-410 cells after $48 \mathrm{~h}$ in culture. Addition of $0.01,0.1$ and $1 \mu \mathrm{M}$ androstenedione elevated the levels of estradiol-17 $\beta$ to 0.028 , 0.3 and $1.21 \mathrm{pg} / \mu \mathrm{g}$ protein, respectively.

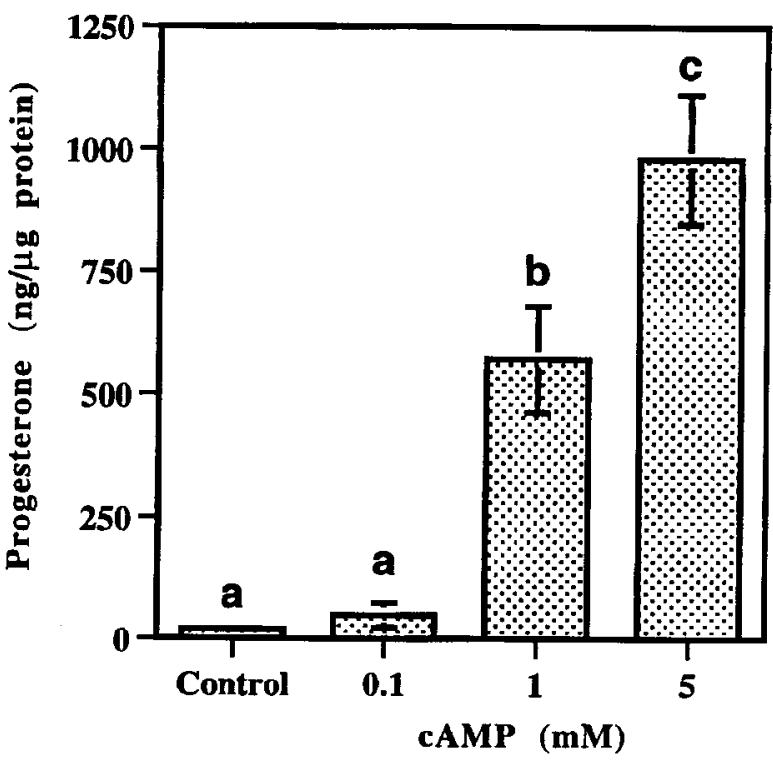

FIGURE 1. Effect of CAMP on progesterone synthesis by JC-410 cells. Cells were cultured for $48 \mathrm{~h}$ in the presence or absence of cAMP. Data are expressed as ng of progesterone per $\mu \mathrm{g}$ of cellular protein. Each bar represents the mean \pm SEM of three independent replications. Bars with different letters are significantly different.

The expression of $3 \beta-\mathrm{HSD}$, aromatase, and P450sce genes by JC-410 cells and primary culture of granulosa cells from medium size follicles is represented by the Northern blot autoradiograms shown in Fig. 3. Expression of these genes was detected in JC-410 cells, as well as in primary cultures. mRNAs for each gene migrated at the same position in both JC-410 and primary cultures. In addition, the levels of expression of each gene was similar in both group of cells. Integrity of the mRNA preparation and consistency in sample loading is demonstrated by similar levels in the expression of the GAPDH gene. 


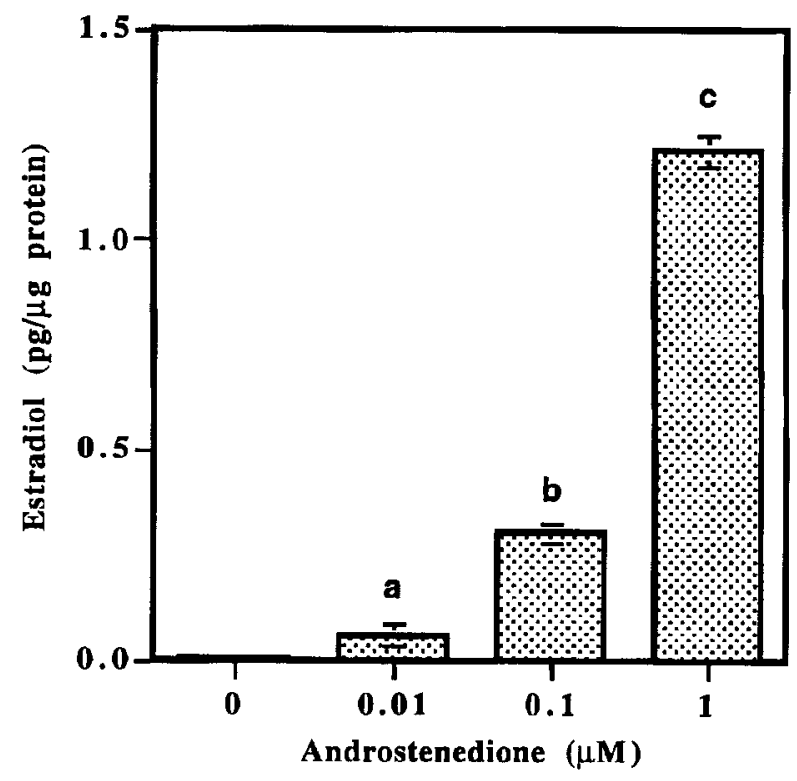

FIGURE 2. Estradiol-17 $\beta$ synthesis by JC-410 cells. Cells were cultured for $48 \mathrm{~h}$ in the presence or absence of androstenedione. Each bar represents the mean \pm SEM of three independent replications. Bars with different letters are significantly different.

The population doubling time of JC-410 was estimated to be $67 \mathrm{~h}$. Cells were in culture for at least sixteen months. Based on this data, and assuming that the first colonies of stable cells appeared by the seventh month, JC-410 cells have been doubling in culture for over 100 generations.

\section{DISCUSSION}

We described the establishment of a stable steroidogenic porcine ovarian granulosa cell line obtained by spontaneous immortalization of a primary culture. The JC-410 cells produced less progesterone than primary cultures of granulosa cells and did not respond to the gonadotropins. In our primary culture conditions progesterone synthesis is stimulated by FSH and LH in granulosa cells from medium size follicles and only by FSH in granulosa cells from small follicles. These results are in agreement with the concept that the gonadotropin receptors are acquired during the process of granulosa cell differentiation (Channing and Ledwitz-Rigby, 1975). Thus, it is quite possible that the LH receptor was not expressed in the less differentiated granulosa cells from small size follicles. Although JC-410 cells produced less progesterone and did not respond to the gonadotropins, they responded to cAMP, to the adenylyl cyclase activator, forskolin and to the $G$ protein activator, cholera toxin. Collectively, the results were interpreted to suggest that JC-410 cells may not express the gonadotropin receptors but retain functional adenylyl cyclase and G-stimulatory proteins, which are able to activate the steroidogenic pathway. Therefore, since the JC-410 cells originated from a FSH-and LH-responsive primary culture, it is possible that during the process of immortalization the JC-410 cells de-differentiated and arrested at an earlier stage of granulosa cytodifferentiation, where the gonadotropin receptors are not expressed (Channing and Kammerman, 1973). Restoration of the gonadotropin response of steroidogenic stable granulosa cells has been reported (Suh et al. 1992, Keren-Tal et al. 1993). Therefore, restoration of response to gonadotropins by transformation with gonadotropin receptor genes should also be possible in JC-410 cells. In addition, hormonal and/or second messenger induction of gonadotropin receptors in $\mathrm{JC}-410$ cells remains to be investigated.

The JC-410 cells expressed P450scc and $3 \beta-H S D$, the key genes necessary for the production of progesterone, as did primary cultures of granulosa cells. The JC-410 cells also expressed the aromatase gene and produced estradiol-17 $\beta$ when the aromatizable androgen, androstenedione, was added to the cultures. The response, in terms of estradiol-17 $\beta$ production in the presence of androstenedione, by the JC- 410 cells was of similar magnitude to our previous report in primary culture of granulosa cells (Xu et al., 1996). This shows that the JC-410 cells retained aromatase activity, a characteristic of granulosa cells. The abundance of $\mathrm{P} 450 \mathrm{scc}$, $3 \beta$-HSD and aromatase mRNAs appears to be similar in cultured JC-410 cells and primary culture of granulosa cells. Therefore, changes in the expression of these genes can not account for the large difference in progesterone synthesis found between JC-410 and primary culture of granulosa cells. Whether this difference is due to changes in the expression of other genes of the steroidogenic pathway remains to be investigated.

Due to the limited availability of granulosa cells and the highly variable results obtained with primary cultures, there is

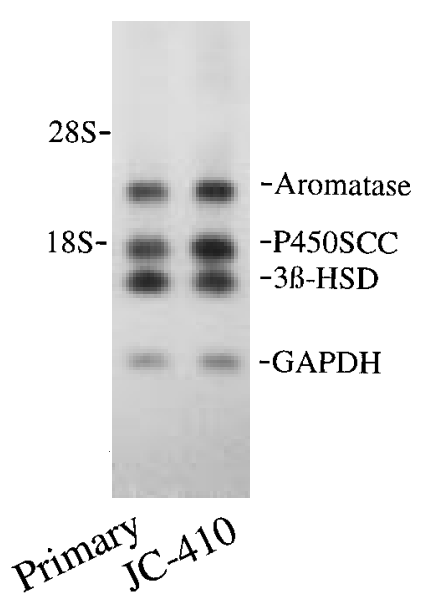

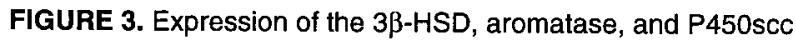
genes by $\mathrm{JC}-410$ cells and primary culture of granulosa cells from medium size follicles. Total RNA $(10 \mu \mathrm{g})$ was analyzed by Northern blot. 
a need for granulosa cells lines to help define the molecular mechanisms controlling steroidogenesis. Several laboratories have established granulosa cell lines by using a variety of methods. Spontaneous immortalization of ovarian granulosa cells was first reported by Bernath et al. (1990). These cells have retained some characteristics of primary cultures, such as the hormonal regulation of fibronectin biosynthesis, but lost the ability to produce progesterone (Colman-Lerner et al. 1995). A steroidogenic stable porcine granulosa cell line, that produced progesterone in response to androstendione or pregnenolone, was also recently reported (Kwan et al. 1996). Other stable granulosa cells, immortalized by transformation with oncogenes were reported to retain basal and regulated progesterone synthesis (Fitz et al. 1989, Suh and Amsterdam, 1990). Steroidogenic cell lines were also generated by transformation of human granulosa-lutein cells with the SV40 gene (Lie et al. 1996), but were reported to have abnormal characteristics as a consequence of the expression of the large $\mathrm{T}$ antigen (Kwan et al. 1997).

We believe that JC-410 is a stable cell line since it has been grown continuously for at least thirty-five passages in culture. The JC-410 cells survived the senescence period (Freshney 1994) at the end of the seventh month in culture. Therefore, it is quite possible that at this point transformation occurred since growth was re-initiated and continued for at least 100 population doubling times. The mechanism of spontaneous transformation is not know, but has been suggested to result from infection of cells with endogenous viruses (Butler, 1991). Although more detailed studies are necessary to investigate expression of viral and/or oncogenic proteins in the JC-410 cells, the data provided in this investigation suggest that they have retained several granulosa cells features, including a reproducible steroidogenic response and the expression of key steroidogenic genes. We conclude that $\mathbf{J C}-410$ is a stable cell line which has lost the ability to respond to the gonadotropins but has retained basal and regulated progesterone biosynthetic capability. This feature may reflect an early stage of granulosa cell differentiation. Therefore, this cell line may serve as an unlimited source of a homogenous porcine granulosa cell population useful for studying the molecular mechanism controlling steroidogenesis and granulosa cell differentiation.

\section{ACKNOWLEDGMENTS}

This research was supported by Saskatchewan Health (Government of Saskatchewan), Medical Research Council of Canada, Natural Sciences and Engineering Research Council of Canada and Clinical Teaching and Research grants to P. J. C. We express our gratitude to Dr. Van Luu The, from Laval University, Dr. T. Wise, from Clay Center, Nebraska and Dr. E. Simpson from the University of Texas, for providing us with cDNA probes for $3 \beta-H S D, P 450$ scc and aromatase, respectively. We thank the National Hormone and Pituitary Program, USDA, for the generous gift of ovine FSH and LH and Intercontinental Packers Ltd. for providing porcine ovaries. We thank Dr. Gheorghe Braileanu and Dr. Mariano Medina for their contributions at the beginning of this project, Dr. Claire Card for critical comments on the manuscript and Christine Meaden for editorial assistance.

\section{REFERENCES}

Amsterdam, A., Zauberman, A., Meir, G., Pinhasi-Kimhi, O., and Suh, B. S. 1988. Cotransfection of granulosa cells with simian virus 40 and Ha-RAS oncogene generates stable lines capable of induced steroidogenesis. Proceedings of the National Academy of Sciences USA 85:7582-7586.

Amsterdam, A. and Selvaraj, N. 1997. Control of differentiation, transformation, and apoptosis in granulosa cells by oncogenes, oncoviruses, and tumor suppressor genes. Endocrine Reviews 18:435-461.

Bernath, V. A., Muro, A. F., Vitullo, A. D., Bley, M. A., Barañao, J. L. and Kornblihtt, A. R. 1990. Cyclic AMP inhibits fibronectin gene expression in a newly developed granulosa cell line by a mechanism that suppresses cAMP-responsive element-dependent transcriptional activation. Journal of Biological Chemistry 265:18219-18226.

Butler, M. 1991. The characteristic and growth of culture cells. In Mammalian Cell Biotechnology A Practical Approach, pp. 1-24. Edited by M. Butler. IRL Press at Oxford University Press, New York, NY, USA.

Colman-Lerner, A. A., Salamone, D. F., Chiappe, M. E. and Barañao, J. L. 1995. Comparative studies between freshly isolated and spontaneously immortalized bovine granulosa cells: protein secretion, steroid metabolism, and responsiveness to growth factors. Journal of Cellular Physiology 164:395-403.

Channing, C. P. and Kammerman, S. 1973. Characteristics of gonadotropin receptors of porcine granulosa cells during follicle maturation. Endocrinology 92:531-540.

Channing, C. and Ledwitz-Rigby, F. 1975. Methods for assessing hormone-mediated differentiation of ovarian cells in culture and in short-term incubations. Methods of Enzymology 39:183-230.

Chedrese, P., Rajkumar, K., Ly, H. and Murphy, B. D. 1988. Dose response of luteinized porcine granulosa cells in vitro to prolactin: dependency on pre-exposure to human chorionic gonadotrophin. Canadian Journal of Physiology and Pharmacology 66:561-566.

Chedrese, P. J. Zhang, D. Luu The, V. Labrie, F. Juorio, A. and Murphy, B. 1990. Regulation of mRNA expression of $3 \beta$ hydroxy-5-ene steroid dehydrogenase in porcine granulosa cells in culture: A role for the protein kinase-C pathway. Molecular Endocrinology 4:1532-1538.

Chomezynski, P. and Sacchi, N. 1987. Single step method of RNA isolation by acid guanidinium thiocyanate-phenol-chloroform extraction. Analytical Biochemistry 162:156-159.

Fainberg, A. P. and Vogelstein, B. 1983. A Technique for radiolabelling DNA restriction endonuclease fragments to high specific activity. Analytical Biochemistry 123:6-13.

Farkash, Y., Timberg, R. and Orly. J. 1986. Preparation of antiserum to rat cytochrome, and its use for ultrastructural localization of the immunoreactive enzyme by protein A-gold technique. Endocrinology 118:1253-1265.

Fitz, T. A., Wah, R. M., Schmidt, W. A. and Winkel, C. A. 1989. Physiologic characterization of transformed and cloned rat granulosa cells. Biology of Reproduction 40:250-258. 
Freshney, R. I. 1994. Biology of the cultured cells. In Culture of Animal Cells, pp.9-16. Edited by R. I. Freshney. Wiley-Liss, New York, NY. USA.

Hinshelwood, M. M., Corbin, C. J., Tsang, P. C. W. and Simpson, E. R. 1993. Isolation and characterization of a complimentary deoxyribonucleic acid insert encoding bovine aromatase cytrocychrome P450. Endocrinology 133:1971-1993.

Hsueh, A. J. W., Adashi, E. Y., Jones, P. B. C. and Welsh, Jr. T. H. 1984. Hormonal Regulation of Differentiation of Cultured Ovarian Granulosa Cells. Endocrine Reviews 5:76-127.

Keren-Tal, I., Dantes, A., Sprengel, R. and Amsterdam, A. 1993. Establishment of steroidogenic granulosa cell lines expressing follicle stimulating hormone receptors. Molecular and Cellular Endocrinology 95:R1-R10.

Kwan, I., Farookhi, R., Huynh, H. T., Murphy, B. D., Turner, J. D and Downey, B. R. 1996. Steroidogenic Properties of a Spontaneously Established Porcine Granulosa Cell Line (PGC-2). Molecular Reproduction and Development 45:299-307.

Kwan, R. W. P., Lie, B-L., Auersperg, N., Thomas, E. E. and Leung, P. C. K. 1997. Biology of Reproduction, Vol. 56, Supplement 1, abstract 446.

Leighton, J. K., Grimes, R. W., Canning, S., and Hammond, J. M. 1993. Expression of the IGF system in primary and immortalized porcine ovarian granulosa cells. Molecular and Cell Endocrinology 97:29-35.

Luu The, V. L., Lachance, Y. Labrie, C., Thomas, J. L. and Labrie, F. 1989. Full length cDNA structure and deduced amino acid sequence of human $3 \beta$-hydroxy-5-ene steroid dehydrogenase. Molecular Endocrinology 3:1310-1312.

Lie, B-L., Leung, E., Leung, P. C. K. and Auersperg, N. 1996. Longterm growth and steroidogenic potential of human granulosalutein cells immortalized with SV40 large T antigen. Molecular and Cellular Endocrinology 120:169-176.

Lowsky, R. and Farookhi, R. 1989. A granulosa cell differentiationstage-specific cytotoxic activity in bovine and rat sera. Biology of Reproduction 40:1265-1273.

Mulheron, G. W., Stone, R. T., Miller, W. L. and Wise, T. 1989. Nucleotide sequence of cytochrome P450 cholesterol side chain cleavage cDNA isolated from porcine testis. Nucleic Acid Research 174:1773.

Patton, A. C. and Collins, W. P. 1992. Differentiation processes of granulosa cells. Oxford Reviews of Reproductive Biology 14:169221.
Rainey, W. H., Sawetawan, C., Shay, J. W., Michael, M. D., Mathis, J. M., Kutteh, W., Byrd, W. and Carr, B. R. 1994. Transformation of human granulosa cells with the E6 and $\mathrm{E} 7$ regions of human papillomavirus. Journal of Clinical Endocrinology and Metabolism 78:705-710.

Richards, J. S. 1994. Hormonal control of gene expression in the ovary. Endocrine Reviews 15:725-751.

Steel, R. G. D. and Torrie, J. H. 1980. Principles and procedures of statistics. A biometrical approach. McGraw-Hill, New York.

Suh, B-S. and Amsterdam, A. 1990. Establishment of highly steroidogenic granulosa cell lines by cotransfection with SV 40 and Ha-ras oncogene: Induction of steroidogenesis by cyclic adenosine $3^{\prime}-5^{\prime}$-monophosphate and its suppression by phorbol ester. Endocrinology 127:2489-2500.

Suh, B-S., Sprengel, R. Keren-Tal, I., Himmelhoch, S. and Amsterdam, A. 1992. Introduction of a gonadotropin receptor expression plasmid into immortalized granulosa cells leads to reconstitution of hormone-dependent steroidogenesis. The Journal of Cell Biology 119:439-450.

Tso, J. Y., Sun, X-H., Kao, T-H., Reece, K. S. and Wu, R. 1985 Isolation and characterization of rat and human gylceraldehyde-3phosphate dehydrogenase cDNAs: genomic complexity and molecular evolution of the gene. Nucleic Acids Research 13:24852502 .

Urban, R. J. and Veldhuis, J. D. 1992. Endocrine control of steroidogenesis in granulosa cells. Oxford Reviews of Reproductive Biology 14:225-262.

Xu, Y. P., Chedrese, P. J. and Thacker, P. A. 1997. Growth hormone as an amplifier of insulin-like growth factor-I action: potentiated oestradiol accumulation. Journal of Endocrinology 152:201-209.

Zeleznik, A. J., Hillier, S. G., Knazek, R. A., Ross, G. T. and Coon, H. G. 1979. Production of long term steroid-producing granulosa cell cultures by cell hybridization. Endocrinology 105:156-162.

Zlotkin, T., Farkash, Y. and Orly, J. 1986. Cell-specific expression of immunoreactive cholesterol side-chain cleavage cytochrome P450 during follicular development in the rat ovary. Endocrinology 119:2809-2820.

Veldhuis, J. D., Klase, P. A. and Hammond, J. M. 1980. Divergent effects of prolactin upon steroidogenesis by porcine granulosa cells in vitro: influence of cytodifferentiation. Endocrinology 107:42-46. 